\title{
THE EFFECT OF BRAND IMAGE TOWARD THE GUEST DECISION TO BUY TOUR PACKAGES AT FLORESSA BALI TOURS DENPASAR
}

\author{
I Gusti Agung Ayu Ari Azthari. \\ Sekolah Tinggi Pariwisata Bali Internasional \\ iga.thari@gmail.com
}

\begin{abstract}
This study conducted at Floressa Bali Tours to determine the effect of brand image which are consist of brand strength, brand favorability, and brand uniqueness with the guest decision to buy tour packages simultaneously and partially. The result of using SPSS program version 21 found that brand strength, brand favorability, and brand uniqueness simultaneously influence tourist's decision with $R$ squared 0,574. It means that $57 \%$ of tourist's decision influenced by brand image and the rest $43 \%$ influenced by other factors. Partially the variable of brand strength and brand uniqueness significantly affect to the tourist's decision to buy the tour packages. Based on the results it is expected the management of Floressa Bali Tours to keep improve their brand image to increase sales and well known by tourists.
\end{abstract}

Keywords: brand image, brand strength, brand favorability, brand uniqueness, tour packages.

\section{INTRODUCTION}

The number of foreign tourist arrivals to the island from 2014 to 2015 grew by $6.24 \%$ percentage, with the number of travelers 3,766,638 in 2014 to 4,001,835 tourists in 2015 (Dinas Pariwisata Provinsi Bali, 2015). The increase in tourist arrivals to the island as a leading tourist destination has been accompanied by the growth of businesses in the field of tourism industry that is travel agency. Data were recorded in Bali Provincial Tourism Office in 2015 showed that among 365 travel agents, travel agents branch 23, 9 MICE travel agents, and 9 retirement travel bureau operating in Bali.

Travel agency can operate as it should, when obtaining a good faith from a company that provides products of traveling facilities as well the trust of consumers as users of services. For travel agencies not easy to maintain both sides of them when they do not have a strategy to be able to keep and maintain how users get to feel satisfaction, in the end be able to obtain the expected profit (Muljadi and Warman, 2014).

Strategy used by the company to win the competition is creating a brand. A brand is a means for companies to compete for market share. (Ambler in Tjiptono 2014). According Chernatony and Segal-Horn (in Tjiptono 2014) branding is not only relevant to producers of goods, but also crucial for service companies, 
because of a strong brand is able to increase customer confidence in purchasing services that are intangible, inseparable, variable and perishable. Strong brands help customers visualize and understand the intangible products. It contributes to the measurement of customer risk (financial, social, security, and psychological) in the purchase of services, especially difficult to evaluate prior to purchase.

According to Keller (2003) brand image is the brand that reflected the notion of consumers holding on consumer memory. The elements that make up the brand image; brand strength, brand favorability, and brand uniqueness. Building a positive brand image can be achieved with strong marketing programs for products and services, unique and has advantages were highlighted, which distinguishes it from other products. A good combination of these elements can create a strong brand image for consumers.

Floressa Bali Tours is a travel agency in Bali that handles international market. Floressa Bali Tours which initially provide only tour packages in Bali is now expanding travel packages to various islands in Indonesia which are; Komodo, Flores, Timor, Sumba, Rote, Sabu, Java, Sumatra, Kalimantan, Sulawesi, and Papua (Interview Results, October 2015). Floressa Bali Tours has attended various marketing activities as well as promoting the company's brand both inside and outside the country ; ASEAN (Association of Southeast Asian Nations), Asean Travel Forum, PATA Mart (Pacific Area Travel Association), PATA Ecotourism, ITB Berlin (International Tourism Bourse), Japan Diving Expo, India Tourism Mart, and the World Tourism Expo. In addition to be widely known to various parts of the world Floressa Bali Tours exploiting information technology through social media such as the company's website, twitter and facebook (Interview Results, October 2015).

Here's a table of data revenue Floressa Bali Tours in the last five years of the period 2010-2015.

Table 1. Data revenue and the number of tourists Floressa Bali Tour of the year 2010 - 2015

\begin{tabular}{|l|l|l|}
\hline Year & $\begin{array}{l}\text { The Number of } \\
\text { Tourists }\end{array}$ & Total Income \\
\hline 2010 & 1353 & $4.944 .863 .439,50$ \\
\hline 2011 & 1000 & $3.334 .787 .405,50$ \\
\hline 2012 & 1102 & $3.806 .108 .656,00$ \\
\hline 2013 & 1021 & $4.463 .141 .450,00$ \\
\hline 2014 & 1280 & $6.542 .727 .483,50$ \\
\hline 2015 & 1015 & $8.036 .564 .154,00$ \\
\hline
\end{tabular}

Sources: Marketing at Floressa Bali Tours

It concluded that the number of tourists and revenue in Floressa Bali Tours still fluctuate so that management needs to do further analysis on brand image. Analysis of brand image is very important because brand image attached continuously will eventually form brand loyalty (Rangkuti, 2004). Positive brand image will give benefits for the company and better known by consumers. In other 
words, consumers will determine the choice to buy a product that has a good image (Kotler, 2005).

Based on the background description this research was to determine the association between the brand image that consists of brand strength, brand favorability, and brand uniqueness in influencing the guest decision to buy a tour packages at Floressa Bali Tours either simultaneously or partially.

\section{RESEARCH METHODS}

This study was conducted at Floressa Bali Tours by using variable brand image (X) as the independent variable (independent variable) which are consist of brand strength (X1), brand favorability (X2), and brand uniqueness (X3) and purchase decisions (Y) as the dependent variable (dependent variable). The population used in this study was tourists who buy a package tour on Floressa Bali Tours and the number of samples set out in this study was 50 respondents. The data used in this research is quantitative data in the form of numbers. The data is the result of the questionnaire score rating.

The analysis used in this research is multiple linear regression analysis comprising determination ( $\mathrm{R}$ squared) is used to determine the contribution of the influence of the independent variables on the dependent variable. F test is a test to determine the effects of independent variables, which are consist of brand strength (X1), brand favorability (X2), and brand uniqueness (X3) simultaneously on the dependent variable that is purchase decision (Y). This study also used $\mathrm{T}$ test to determine effects of independent variables $(\mathrm{X})$ partially toward dependent variable (Y). The entire quantitative analysis that is used in data processing assisted with SPSS (Statistical Product and Service Solution) version 21.0.

\section{DISCUSSION}

Based on the results of data SPSS output that is obtained, it is known that the whole question items that make up the variables on brand image that consists of brand strength (X1), brand favorability (X2), brand uniqueness (X3) and purchase decision (Y) has a value of Pearson Correlation $>0.279$. Thus the items in the questionnaire are a valid question.

Then reliability test results show that the value of Cronbach Alpha on the entire items in question is greater than the critical value $(0.902>0.60)$. Thus the items in the questionnaire question stated reliably.

Table 2. Test Results of Determination (R Squared)

\begin{tabular}{|l|l|l|l|l|}
\hline Model & $\mathrm{R}$ & R Square & $\begin{array}{l}\text { Adjusted } \\
\text { Square }\end{array}$ & $\begin{array}{l}\text { Std. Error of } \\
\text { the Estimate }\end{array}$ \\
\hline 1 &, $758^{\mathrm{a}}$ &, 574 &, 547 & 2,54099 \\
\hline
\end{tabular}

Sources: Primary data, 2016 
The results of $\mathrm{R}$ squared $=0.574$ It means that a $57 \%$ rating of purchase decision to buy a tour packages in Floressa Bali Tours affected by variables brand image that consists of brand strength, brand favorability, and brand uniqueness.

Table 2. Test Results of $\mathbf{F}$ Test

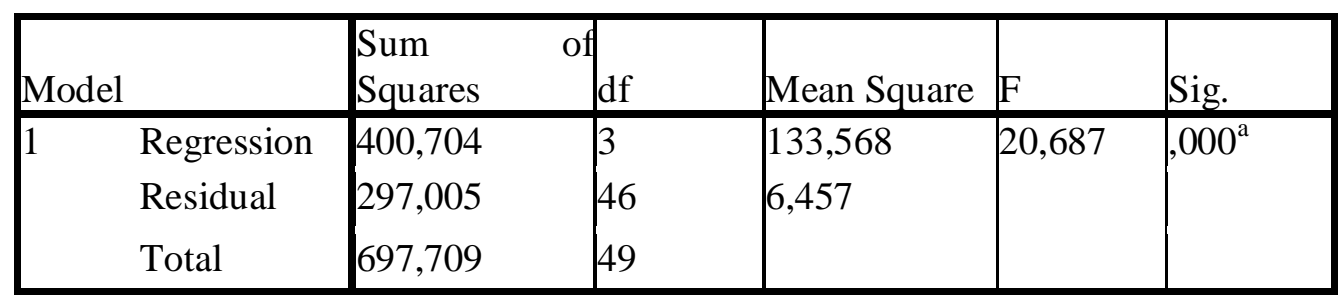

Sources: Primary data, 2016

Test results with SPSS Statistics that value of F count $20.687>$ F table 3,20 and at a significance level of $0.000<0.05$ It means that the independent variables is brand image that consists of brand strength (X1), brand favorability (X2), and brand uniqueness (X2) has positive and significant simultaneously (together) against the guest decision to buying tours packages at Floressa Bali Tours.

Table 3. Test Result of T Test

\begin{tabular}{|c|c|c|c|c|c|c|}
\hline \multirow{2}{*}{\multicolumn{2}{|c|}{ Model }} & \multicolumn{2}{|c|}{$\begin{array}{l}\text { Unstandardized } \\
\text { Coefficients }\end{array}$} & \multirow{2}{*}{\begin{tabular}{|l|}
$\begin{array}{l}\text { Standardized } \\
\text { Coefficients }\end{array}$ \\
Beta \\
\end{tabular}} & \multirow[b]{2}{*}{ t } & \multirow[b]{2}{*}{ Sig. } \\
\hline & & B & Std. Error & & & \\
\hline 1 & (Constant) & 1,852 & 2,420 & &, 765 & 448 \\
\hline & $\mathrm{X} 1$ &, 438 &, 151 & ,408 & 2,894 &, 006 \\
\hline & $\mathrm{X} 2$ &, 241 &, 155 & ,212 & 1,553 &, 127 \\
\hline & X3 &, 330 &, 144 &, 266 & 2,293 &, 026 \\
\hline
\end{tabular}

Sources: Primary data, 2016

The results of the partial test (T test) variable brand strength (X1) positive and significant impact on purchase decisions (Y) on Floressa Bali Tours this is indicated by the level of variable significance of 0.006 which means it is still below the real level or the level of significant $(\alpha)$ used is $5 \%(0.05)$ and $t$ count greater than the value $t$ table $(2.894>1.677)$.

On brand favorability variable (X2) does not occur a significant and positive influence on purchase decisions (Y) on Floressa Bali Tours this is indicated with a significance level of 0.127 that is larger than the real level of 0.05 and $t$ count smaller than the value $t$ table $(1.553<1.677)$.

Variable brand uniqueness (X3) influence on purchase decisions (Y) because it has a variable significance level of 0.026 , which is smaller than the real level of 0.05 and $t$ count, is greater than the value $t$ table $(2.293>1.677)$. 


\section{CONCLUSION}

Floressa Bali Tours is expected to maintain and improve strength, favorability and uniqueness in the minds of tourists so it can better influence purchase decision in buying tour packages. Floressa Bali Tours also expected to be able to retain existing customers and expand market share. Floressa Bali Tours is expected to improve the quality of service to consumers as well as the use of marketing mix strategy in competing with other travel agents, so as to increase tourist arrivals and also curiosity back tourists using the services of Floressa Bali Tours. In a subsequent study that will examine the suggested brand image to further develop research topic by adding new variables and sample to be investigated so that the conclusions would be better.

\section{REFERENCES}

Arcana Komang Trisna Pratiwi. 2014. Pengaruh Brand Awareness dan Brand Personality Terhadap Pembentukan Brand Image The Westin Resort Nusa Dua Bali. Jurnal Ilmiah Hospitality Management Sekolah Tinggi Bali Internasional, Denpasar.

Dinas Pariwisata Propinsi Bali. 2015.Distribusi Kedatangan Wisatawan Mancanegara ke Bali Setiap Bulan Tahun 2008-2015.

Dinas Pariwisata Propinsi Bali.2015. Statistik Pariwisata Bali 2015.

Keller Kevin Lane. 2003. Strategic Brand Management: Building, Measuring, and Managing Brand Equity. Second Edition. New Jersey: Pearson Education, Inc.

Kotler Philip dan Armstrong Gary. 2001. Prisip-Prinsip Pemasaran. Jakarta: Erlangga.

Kotler Philip. 2005. Manajemen Pemasaran. Jilid 1 dan 2. Jakarta: PT. Indeks Kelompok Gramedia.

Leliga Juliani Felicia.2013. Analisa Pengaruh Brand Image Terhadap Customer Loyalty Dengan Customer Satisfaction Sebagai Mediator Pada The Dreamland Luxury Villas And Spa Bali. Jurnal Manajemen Perhotelan Universitas Kristen Petra, Surabaya. http://studentjournal.petra.ac.id (diakses tanggal 3/1/2016 9:24 PM)

Majalah Travel+Leisure New York Amerika memberikan peringkat pulau-pulau terbaik dunia tahun 2015.

http://www.disparda.baliprov.go.id/id/Majalah-Travel-Leisure-New- YorkAmerika-memberikan-peringkat-pulau-pulau-terbaik-dunia- tahun-2015(diakses tanggal 2/16/16 8:44 PM)

Journal of Business on Hospitality and Tourism 
Mengubah Data Ordinal Ke Data Interval Dengan Metode Suksesif Interval (MSI) http://www.jonathansarwono.info/teori_spss/msi.pdf (diakses tanggal 4/13/16 9.20 PM)

Muljadi A.J dan Warman Andri. 2014. Kepariwisataan dan Perjalanan, Edisi Revisi.Jakarta: PT. Raja Grafindo Persada.

Pantiyasa I Wayan. 2015. Pedoman Penulisan Skripsi Diploma IV. Diktat Kuliah pada Jurusan Manajemen Kepariwisataan Sekolah Tinggi Pariwisata Bali Internasional.

Rangkuti Freddy. 2004. The Power of Brands. Jakarta: PT. Gramedia Pusataka Utama

Sangadji Mamang Etta dan Sopiah. 2013. Perilaku Konsumen. Yogyakarta: Andi.

Sugiyono. 2007. Metode Penelitian Bisnis. Bandung: CV Alfabeta.

Sugiyono. 2014. Metode Penelitian Manajemen.Bandung: Alfabeta.

Tjiptono Fandy.2014. Pemasaran Jasa. Yogyakarta: Andi

Utama I Gusti Bagus Rai, Mahadewi Ni Made Eka. 2012. Metodologi Penelitian Pariwisata dan Perhotelan. Yogyakarta: Andi.

Wiratnaya I Nyoman. 2014. Pengaruh Citra Merek Terhadap Minat Beli Wisatawan Pada Komaneka Resorts \& Spa Group Di Kawasan Pariwisata Ubud Gianyar. Jurnal Ilmiah Hospitality Management Sekolah Tinggi Pariwisata Bali Internasional, Denpasar. 